\title{
Muhammadiyah Primary School Sanitation Description in Sawangan Depok 2018
}

\author{
Ernyasih, Triana Srisantyorini \\ Departement of Environmental Health, Faculty of Public Health, Universitas Muhammadiyah Jakarta \\ *ummi.rifali@gmail.com
}

\begin{abstract}
Background: Children are the next generation of the nation, so they need a healthy environment in order to work optimally and they spend more time at school so school sanitation is needed. School sanitation is an important element in efforts to improve the quality of education. Increased access to sanitation in schools can have a significant impact on improving the quality of students' health at school. Only around $11.43 \%$ of schools from all levels in Indonesia have separate and functioning latrines. Whereas an average of $52.49 \%$ of schools have inappropriate toilets, are not separate, or do not function. Muhammadiyah Primary School Sawangan, is one of the places of education where environmental health conditions are quite alarming and have a high risk of diarrhea. The purpose of this research is to know the description of school environmental sanitation in Muhammadiyah primary School Sawangan based on the Decree of the Minister of Health RI Number 1429/Menkes/SK/XII/2006. Methods: The research method used is descriptive qualitative approach. This research was conducted with an observation approach and in-depth interviews related to school sanitation facilities and informants were the Principal and janitor in November 2018. Conclusion: Based on the Decree of the Minister of Health RI No. 1429/Menkes/SK/XII/2006, clean water facilities at primary School Muhammadiyah, Sawangan are categorized as good, toilet facilities are not appropriate, SPAL facilities are appropriate, waste disposal facilities are not appropriate.
\end{abstract}

Keywords: Sanitation, Elementary School, Description.

\section{INTRODUCTION}

In an Islamic perspective, health is a blessing and a gift that must be grateful so that all people can carry out their duties and obligations of life well. In good health, humans can do better. Although health is a natural human need, there are still many who ignore it (1).

Health is influenced by one of them is the environment. A good environment will have a positive effect on optimal health status. The scope of environmental health includes the provision of clean water, human waste disposal, garbage disposal, waste water disposal. If the environment is not good, there is a risk of disease, one of which is diarrhea. For this reason, supervision is needed on various environmental factors that influence the degree of public health (2). Diarrhea is a waterborne disease or also known as waterborne disease. This happens when the water has been polluted (3). 
Diarrheal disease is still a public health problem in developing countries like Indonesia, because of its high morbidity and mortality. Diarrhea is included in 10 diseases that often cause extraordinary events. The morbidity survey conducted by the Diarrhea Subdit, Ministry of Health from 2000 to 2010 shows a tendency for the incidence to rise. In 2000 the IR of Diarrhea was 301/1000 population, in 2003 it rose to $374 / 1000$ population, in 2006 it increased to $423 / 1000$ population and in 2010 it became 411/1000 population. Extraordinary events (KLB) diarrhea also still occur frequently, with CFR still high. In 2008 there were outbreaks in 69 subdistricts with a total of 8133 cases, 239 deaths (CFR 2.94\%). In 2009 there were outbreaks in 24 districts with a total of 5,756 cases, with 100 deaths (CFR $1.74 \%$ ), while in 2010 there were outbreaks of diarrhea in 33 districts with 4204 patients with 73 deaths (CFR $1.74 \%$.) . Diarrhea is the second leading cause of death in children in Indonesia (4).

Children are the next generation of the nation, so they need a healthy environment so they can work optimally and they spend more time at school so school sanitation is needed. School sanitation is an important element in efforts to improve the quality of education. Increased access to sanitation in schools can have a significant impact on improving the quality of health and comfort of students in schools and indirectly contributing to an increase in school participation (5). Based on the Data and Statistics Center for Education and Culture (PDSPK), the Secretariat General of the Ministry of Education and Culture in 2017, the number of primary schools that do not have latrines as a means of school sanitation is $12.9 \% \quad(19,123$ Elementary Schools). Whereas primary schools with separate toilets that are in good condition are $31.40 \%$ (46,458 schools) and $64.76 \%$ $(96,002)$ primary schools have access to clean water (5).

Sanitation indicators in accordance with Sustainable Development Goals (SDGs) include access to a source of clean and available water that is available throughout time, access to proper and separate school latrines, waste water management and waste management (4). School Sanitation is the mandate of the law, especially Health Law Number 36 Year 2009 regarding Health. Article 79 emphasizes that "School Health is organized to improve the ability of life of students in a healthy environment so that students can learn, grow, and develop harmoniously and as high as possible into quality human resources (5).

The UNESCO study found that globally, 1 in 5 girls over the age of primary school did not continue their education to secondary education, one of which was due to improper sanitation facilities in schools. The same thing, 1 out of 6 female students who are menstruating are forced to not go to school (truant) because of inadequate sanitation facilities in schools. Finally, elementary school-age children can be agents of change in clean and healthy living in their families and environments (5).

Only around $11.43 \%$ of schools from all levels in Indonesia have separate and functioning latrines. Whereas an average of $52.49 \%$ of schools at all levels have inappropriate toilets, are not separate, or do not function. This means that nationally half of school students have limited access to latrines during study time at school. In fact, there are still $36.08 \%$ of 
schools that have no access at all. Even though poor sanitation facilities in schools can affect the quality of education, such as loss of study time and decreased student productivity due to absence from school (5).

Muhammadiyah Primary School Sawangan, is one of the places of education where environmental health conditions are quite alarming and have a high risk of diarrhea. In addition, students are still often not paying enough attention to personal hygiene and showing symptoms of being infected with diarrhea. This can be seen from a number of students who often do not go to school because of an upset stomach. The purpose of this research is to know the description of school environmental sanitation in Muhammadiyah Sawangan PrimarySchool based on the Decree of the Minister of Health of the Republic of Indonesia Number 1429 / Menkes / SK / XII / 2006.

\section{METHODS}

The research method used is a descriptive research method using a qualitative approach that is describing the sanitation conditions in SD Muhammadiyah Sawangan Based on the Decree of the Minister of Health RI No.1429 / Menkes / SK / XII / 2006. This research was conducted with an observation approach and in-depth interviews related to school sanitation facilities in the form of clean water, school toilets, SPAL, and waste disposal facilities in schools. The location of this study was Muhammadiyah Sawangan Primary School conducted in November 2018. The research informants were the Principal and janitor.

\section{RESULT}

\section{Clean Water Facilities}

Based on Table 1, the quality of clean and good water facilities is based on Decree of the Minister of Health RI No. 416 of 1990 as measured by the physical requirements of water, the quality will be good if the water used as clean water facilities is colorless and odorless. Based on observations at primary school Muhammadiyah Sawangan, water quality is good and clean because it is colorless and odorless.

Table 1. Clean Water Facilities in Muhammadiyah Sawangan Primary School

\begin{tabular}{|c|c|c|c|}
\hline \multicolumn{4}{|c|}{ Clean Water Facilities } \\
\hline \multirow[b]{2}{*}{ No. } & \multirow{2}{*}{$\begin{array}{l}\text { Decree of the } \\
\text { Minister of } \\
\text { Health RI No } \\
1429 \text { tahun } 2006\end{array}$} & \multicolumn{2}{|c|}{ Result } \\
\hline & & Correct & Incorrect \\
\hline 1. & $\begin{array}{l}\text { The quality of } \\
\text { clean water that } \\
\text { meets the health } \\
\text { requirements in } \\
\text { accordance with } \\
\text { Kep.Men.Kes } \\
\text { No.416 of 1990, } \\
\text { regarding the } \\
\text { requirements and } \\
\text { supervision of } \\
\text { water quality } \\
\text { (color, smell and } \\
\text { taste) }\end{array}$ & $\sqrt{ }$ & \\
\hline 2. & $\begin{array}{l}\text { Distance of } \\
\text { wells / clean } \\
\text { water facilities } \\
\text { with a pollution } \\
\text { source of at least } \\
10 \text { meters }\end{array}$ & $\sqrt{ }$ & \\
\hline
\end{tabular}


Meanwhile, the distance of clean water sources to pollutants (septic tanks and landfills) is a minimum of 10 meters. From the results of measurements at primary school Muhammadiyah have a distance of clean water sources with a good source of pollutants because they are 11 meters away from the septic tank and 120 meters from the final waste treatment site.

\section{Toilet}

Table 2. Latrines / Toilets in the Muhammadiyah Sawangan Primary School

\begin{tabular}{|c|c|c|c|}
\hline \multicolumn{4}{|c|}{ Latrines / Toilets } \\
\hline \multirow[b]{2}{*}{ No } & \multirow{2}{*}{$\begin{array}{l}\text { Decree of the } \\
\text { Minister of } \\
\text { Health RI No } \\
1429 \text { tahun } \\
2006\end{array}$} & \multicolumn{2}{|c|}{ Result } \\
\hline & & Correct & Incorrect \\
\hline 1. & $\begin{array}{l}\text { Availability of } \\
\text { separate toilets } \\
\text { between men } \\
\text { and women } \\
\text { (WC Student } \\
1: 25 \text { and WC } \\
\text { Student } 1: 40 \text { ) }\end{array}$ & & $\sqrt{ }$ \\
\hline 2. & $\begin{array}{l}\text { The toilet must } \\
\text { be clean, no } \\
\text { stagnant water }\end{array}$ & $\sqrt{ }$ & \\
\hline 3. & $\begin{array}{l}\text { Availability of } \\
\text { ventilation holes } \\
\text { which are } \\
\text { directly } \\
\text { connected to the } \\
\text { outside air } \\
\text { (ventilation) }\end{array}$ & & $\sqrt{ }$ \\
\hline 4. & $\begin{array}{l}\text { Water reservoirs } \\
\text { do not become } \\
\text { mosquito } \\
\text { breeding } \\
\text { grounds }\end{array}$ & & $\sqrt{ }$ \\
\hline
\end{tabular}

Based on Table 2, the results of observations made on school latrines/toilets in Muhammadiyah elementary school have poor latrines / toilets. The condition of the toilet / toilet is clean and there is no stagnant water, but there is no ventilation, and the water reservoir can become a den for mosquitoes because it is rarely cleaned. The incompatibility of good toilet / toilet conditions at primary school Muhammadiyah is in the toilet / toilet that is not separated between men and women, the unavailability of ventilation and storage tanks to become mosquito breeding grounds.

P1: "Toilets are not separate because there is no place, but the number is sufficient for students, I have never seen any students queuing or scrambling to enter the toilet. There are 2 toilets that can be used and 3 that cannot be used, a total of 5 toilets and 450 students. P2: "No ventilation has been made because all walled and water in December is rarely disposed of and rarely cleaned".

\section{Sewerage}

The results of observations on Sewerage at primary school Muhammadiyah Sewerage are made of water-resistant material, namely paralon, the channel is tightly closed, the water is flowing and does not pollute the school environment. Based on interviews with janitors before being flowed to the paralon pipe there is a control tub and filter, to filter waste before it flows into the paralon pipe to the residents Sewerage.

P2: "The water channel uses a hose pipe, it is tightly closed in the ground, there is a control tub before it flows into the paralon, it is equipped with a filter. Cleaning is done on the control tub when the water seems stagnant. Water that flows only from the toilet. And for the end the 
water does not flow into the septic tank but instead flows to the residents Sewerage and ends up in the river".

The results of observations on Sewerage at primary school Muhammadiyah Sewerage are made of water-resistant material, namely paralon, the channel is tightly closed, the water is flowing and does not pollute the school environment. Based on interviews with janitors before being flowed to the paralon pipe there is a control tub and filter, to filter waste before it flows into the paralon pipe to the residents Sewerage.

Table 3. Sewerage in the Muhammadiyah Sawangan Primary School

\begin{tabular}{|c|c|c|c|}
\hline \multicolumn{4}{|c|}{ Sewerage } \\
\hline \multirow[b]{2}{*}{ No } & \multirow{2}{*}{$\begin{array}{l}\text { Decree of the } \\
\text { Minister of Health } \\
\text { RI No } 1429 \text { tahun } \\
2006\end{array}$} & \multicolumn{2}{|c|}{ Result } \\
\hline & & Correct & Incorrect \\
\hline 1. & $\begin{array}{l}\text { Sewerage is } \\
\text { separate from the } \\
\text { rainwater finisher }\end{array}$ & $\sqrt{ }$ & \\
\hline 2. & $\begin{array}{l}\text { Sewerage is made } \\
\text { of waterproof } \\
\text { material }\end{array}$ & $\sqrt{ }$ & \\
\hline 3. & $\begin{array}{l}\text { The existence of } \\
\text { Sewerage does not } \\
\text { pollute } \\
\text { environment }\end{array}$ & $\sqrt{ }$ & \\
\hline 4. & $\begin{array}{l}\text { Waste water, } \\
\text { discharged through } \\
\text { a septic tank and } \\
\text { then absorbed into } \\
\text { the ground }\end{array}$ & $\sqrt{ }$ & \\
\hline 5. & $\begin{array}{l}\text { Disposing of waste } \\
\text { water is given a } \\
\text { control tub at a } \\
\text { certain distance so } \\
\text { that it is easy to } \\
\text { clean in the event of } \\
\text { a blockage }\end{array}$ & $\sqrt{ }$ & \\
\hline
\end{tabular}

P2: "The water channel uses a paralon pipe, it is tightly closed in the ground, there is a control tub before it flows into the paralon, it is equipped with a filter. Cleaning is done on the control tub when the water seems stagnant. Water that flows only from the toilet. And for the end the water does not flow into the septic tank but instead flows to the residents Sewerage and ends up in the river".

\section{Waste Disposal Facilities}

Table 4. Waste Disposal Facilities in the School Environment of Muhammadiyah Sawangan Primary School

\begin{tabular}{|c|c|c|c|}
\hline \multicolumn{4}{|c|}{ Waste Disposal Facilities } \\
\hline \multirow[b]{2}{*}{ No } & \multirow{2}{*}{$\begin{array}{l}\text { Decree of the } \\
\text { Minister } \\
\text { Health RI No } \\
1429 \text { tahun } 2006\end{array}$} & \multicolumn{2}{|c|}{ Result } \\
\hline & & Correct & Incorrect \\
\hline 1. & $\begin{array}{l}\text { Availability of } \\
\text { trash can in every } \\
\text { room }\end{array}$ & & $\sqrt{ }$ \\
\hline 2. & $\begin{array}{l}\text { Availability of } \\
\text { temporary } \\
\text { garbage from all } \\
\text { rooms to } \\
\text { facilitate } \\
\text { transportation }\end{array}$ & & $\sqrt{ }$ \\
\hline 3. & $\begin{array}{l}\text { Tempat } \\
\text { pembuangan } \\
\text { sampah dengan } \\
\text { ruang kelas } \\
\text { berjarak minimal } \\
10 \text { meter }\end{array}$ & & $\sqrt{ }$ \\
\hline
\end{tabular}

Based on the results of research trash cans are outside the room to facilitate cleaners to transport garbage. Trash bins are available only in every corner of the room. Temporary garbage is not available, garbage is only collected behind a security guard post until there is transportation of garbage by the Sawangan garbage officer 
once a week. The landfill is only 2 meters away from the classroom.

P2: "Garbage is only provided 1 for some classes and placed in the corner. If garbage is usually only put behind the security post until the garbage officer is taken from sawangan once a week. "

\section{DISCUSSION}

\section{Clean Water Facilities}

Clean water facilities as a basic means of sanitation that is needed in every daily human activity. Apart from being a source of drinking water, clean water is also much needed in other household activities such as washing, cooking and bath activities (6).

Based on observations at primary school Muhammadiyah Sawangan, the school has good quality clean water in accordance with Minister of Health Decree No. 416 of 1990 on the physical requirements of water that is odorless, tasteless and colorless. The specified physical water requirements are useful for improving health status and in order to avoid health problems. Under certain conditions that cause water to no longer function as intended, it will cause various disturbance to living things, including disturbance to human health. Unclean water can cause 20-30 kinds of infectious diseases. Infectious diseases that are often experienced are diarrhea. This is in accordance with what Puspawati said, that the provision of clean water must meet quality and quality requirements so as not to cause disease (7).

The results of measurements in research at primary school Muhammadiyah Sawangan is the distance of the Sewerage which is more than 10 meters from the source of pollution (septic tanks and landfills). If the distance is too close then the water source will be more easily and quickly contaminated (8).

Clean water facilities in primary school Sawangan in accordance with the Decree of the Minister of Health of the Republic of Indonesia Number. 1429 / MENKES / SK / 2006 concerning guidelines for the implementation of school environmental health which states "school sanitation facilities on clean water quality must meet health requirements in accordance with Minister of Health Decree No. 416 of 1990, regarding water requirements and supervision. And is a minimum of 10 meters from the source of pollution (Sewerage, septic tank and landfill)" (6).

\section{Toilet}

Based on the understanding issued by the Ministry of Health of the Republic of Indonesia a toilet / toilet is a room that functions as a place to dispose of human waste (feces) consisting of squats and goose necks equipped with a place to collect human excrement and water to clean dirt.

Human waste consists of feces and urine, both of which can be a problem for humans and environmental pollution, and therefore must be treated in a sanitary manner. Sanitary treatment can provide direct benefits such as decreasing the incidence of typhoid abdominal disease, cholera, bacillary dysentery, etc. while indirectly, such as increasing environmental cleanliness (3). Toilet facilities / toilets in primary schools are urgently needed, this is of course for the sake of protecting or protecting students from the risk of diseases that can arise due to the processing of feces or improper toilet/toilet facilities. 
In addition to not separating male and female latrines/toilets, the ideal number of latrines/toilets does not meet the requirements, because the number of male students at primary school Muhammadiyah Sawangan is 226 students so that they need 5 latrines/toilets to meet the proportion of the number of latrines / toilets while for the number 224 female students who need 9 latrines / toilets to fulfill the proportion of the number of latrines / toilets. The total is based on the proportion of the number of latrines / toilets and the number of students is 14 toilets / toilets for all male and female students, 450 students. Based on observations and interviews conducted, school sanitation facilities in latrines / toilets in primary school Muhammadiyah Sawangan, there are 5 toilets but only 2 toilets can be used, while 3 toilets are in a damaged condition. In addition, toilets do not have ventilation and water is only accommodated in December and can become mosquito breeding sites because it can be said that the toilet is not in accordance with the Decree of the Minister of Health of the Republic of Indonesia No. 1429 / MENKES / SK / XII / 2006 concerning guidelines for administering school health.

Bathroom hygiene must be maintained, for that in addition to cleaning efforts carried out there must be regular school hygiene and sanitation promotions in order to increase student knowledge. Draining the tub is also done at least once a week to avoid the proliferation of vectors causing diseases such as Aedes Aegypti mosquitoes.

\section{Sewerage}

Waste water in schools that do not have Sewerage has the potential to seep into the ground and pollute the environment and can cause odors in the surrounding area. The mildest effect if the water is used for human activities is the disruption of life comfort. Poor appearance and unpleasant odor, will disturb health. This Sewerage is not only limited to waste management to treat waste to be environmentally friendly but has shifted to norms of aesthetics or cleanliness and beauty. Wastewater consists of 3 important fractions, namely: Feces which potentially contain pathogenic microbes, urine which generally contains nitrogen and phosphorus as well as the possibility of micro-organisms, and the last is gray water which is water used from kitchen washing, wash and bathroom (9).

Sewerage must be made of waterproof materials. If Sewerage is not made of waterproof materials, wastewater has the potential to seep into the soil around sewerage channels. Based on observations and interviews the existence of Sewerage at primary school Muhammadiyah Sawangan is a closed and waterproof type of Sewerage so that the Sewerage of this school is classified as good and does not pollute the school environment, in addition there is a useful control tub to facilitate cleaning so it can flow smoothly. However, the final channel is channeled to the Sewerage of citizens who will end up in the river. Based on the discussion, sewerage at primary school Muhammadiyah Sawangan in accordance with the Republic of Indonesia Ministry of Health Regulation No. 1429 / MENKES / SK / XII / 2006 regarding guidelines for school health management in Sewerage explained that " Sewerage must be made of waterproof and closed materials, the presence of Sewerage does not pollute the environment, waste water is discharged through a septic tank which is then 
absorbed into the ground, and the discharge of the wastewater is given a control tub at a certain distance so that it is easy to clean up when a blockage occurs so that it can flow smoothly" (6).

\section{Waste Disposal Facilities}

In Law No. 18 of 2008 concerning waste management is explained the stages of waste management which include the sorting stage, the collection stage, the transportation stage, and finally the waste processing stage. If garbage is not properly disposed of, it can cause health problems. Open trash dumps become a den of rats, flies, mosquitoes, cockroaches, and other insects that carry disease (10). This is also in line with Notoadmojo 2011 which states that waste is closely related to human health so it must be managed properly. The condition of the garbage disposal facilities at primary school Muhammadiyah Sawangan is that the garbage bin is not inside the room but outside the room and is not equipped with a lid. In addition, there is no Temporary Garbage Collection Site to facilitate the transportation or destruction of waste. Plastic waste is burnt in the open air, hazardous chemicals are released and spread in the air, and toxic ash creates soil and water pollution. in the short term it will cause lung infections, coughs and eye infections.

Referring to the explanation above, in general, garbage disposal in primary school Muhammadiyah Sawangan is not appropriate due to the absence of closed waste bins in each room, the unavailability of temporary dumpsite to facilitate the transportation or destruction of waste. In fact, in the Decree of the Minister of Health of the No. 1429 / MENKES / SK / XII2006 explains that "in every room must have a closed trash bin, the presence of
TPS from all rooms to facilitate the transportation or destruction of rubbish, and the placement of waste disposal with a class space of at least 10 meters" (6).

\section{CONCLUSION}

Clean water facilities at primary school Muhammadiyah Sawangan are categorized as good because they meet the requirements based on Decree of the Minister of Health of the RI No.1429 of 2006. Toilet facilities in schools are categorized as not in accordance with Decree of the Minister of Health of the RI No.1429 in 2006 because there is no separation between latrines / toilets for men and women, although the conditions of the toilets are clean and there is no standing water, there is no ventilation, and storage tanks are at risk of becoming mosquito breeding grounds. At the sewerage facilities in schools are categorized according to Decree of the Minister of Health of the RI No.1429 in 2006 because sewerage is separated from rainwater finishing channels, sewerage is made of waterproof and closed material and there is a control tub. The waste disposal facilities are categorized as inappropriate according to Decree of the Minister of Health of the RI No.1429 of 2006 due to the absence of closed trash bins in each room, there is no temporary garbage to facilitate the transportation or destruction of waste.

It is necessary to make a mark or label of separation between men's and women's latrines / toilets to make a difference between men's and women's toilets and there is a closed trash can in every room for polling stations to facilitate cleaning. 


\section{ACKNOWLEDGMENT}

Thank you to primary school Muhammadiyah Sawangan, Dean of FKM UMJ and all who helped in this research.

\section{CONFLICT OF INTEREST}

The authors state they have no conflict of interest, and no affiliation or connection to or with any entity or organization, which may raise a question of bias in discussion and conclusion of the manuscript.

\section{REFERENCE}

1. Sumantri A. Kesehatan Lingkungan. Edisi III. Kencana Prenada Media Group; 2010.

2. Notoatmodjo S. Kesehatan Masyarakat, Ilmu dan Seni. Rineka Cipta; 2011.

3. Chandra B. Pengantar Kesehatan Lingkungan. Buku Kedokteran EGC; 2012.

4. Kementerian Kesehatan Republik Indonesia. Buletin Jendela Data dan Informasi Kesehatan Triwulan II. Jakarta; 2011.

5. Kementerian Pendidikan dan Kebudayaan. Pengembangan Pedoman Sanitasi Sekolah Dasar. Kementerian Pendidikan dan Kebudayaan; 2017.

6. Kementerian Kesehatan Republik Indonesia. Keputusan Menteri Kesehatan Republik Indonesia No. 1429/MENKES/SK/2006 tentang Pedoman Penyelenggaraan Kesehatan Lingkungan Sekolah. 2006.

7. Puspawati C, Prabowo K, Pujiono. Kesehatan Lingkungan, Teori dan Aplikasi. EGC; 2019.

8. Sari GM. Gambaran Sanitasi Sekolah Dasar Negeri dan Madrasah Ibtidaiyah di Kecamatan Jelbuk
Kabupaten Jember. Universitas Jember; 2011.

9. Rosiy A. Studi Deskriptif Sarana Sanitasi Dasar pada Sekolah Dasar di Kota Tembilangan Kabupaten Indragiri Hilir Provinsi Riau Tahun 2012. Universitas Indonesia; 2012.

10. Undang-undang Nomor 18 Tahun 2008 tentang Pengelolaan Sampah. 2008. 